\title{
Pripovijest o Davidu i Bat-Šebi prema rabinskoj literaturi
}

Kotel DaDon*

kdadon@gmail.com

https://orcid.org/0000-0002-3542-3754 https://doi.org/10.31192/np.18.2.10

UDK: 26-254

26-243.6David, kralj

2-423.5:26-243.6

Izvorni znanstveni rad / Original scientific paper Primljeno: 15. ožujka 2020. Prihvaćeno: 4. lipnja 2020.

Autor uz pomoć rabinske literature analizira jednu od najzanimljivijih pripovijesti iz Biblije, onu o kralju Davidu i Bat-Šebi. Kralj David bio je vladar, duhovni vođa, pjesnik koji je spjevao Psalme, velik poznavatelj Tore, začetnik židovske kraljevske dinastije, a prema židovskoj tradiciji, jedan od njegovih potomaka bit će čak i Mesija. No, prema biblijskoj pripovijesti, očito je da je David teško griješio, počinivši grijeh preljuba i umorstva nedužna čovjeka. Takvi grijesi ne odgovaraju slici koju imamo o njemu. Rad nastoji na temelju rabinske literature objasniti što se zapravo dogodilo u ovoj pripovijesti. Je li kralj David doista tako sagriješio? Nakon uvoda slijedi biblijska pripovijest, a potom tumačenje Mudraca o vezi kralja Davida i Bat-Šebe te rasprava o odnosu Urije i Bat-Šebe i o pitanju preljuba. Slijedi analiza grijeha i kazne te raznih pitanja koja nastaju kao posljedica toga grijeha. U svom istraživanju autor se služi raznovrsnim izvorima rabinske književnosti, koji su nastajali od vremena Talmuda, preko srednjega vijeka sve do modernih vremena. Velik dio te literature prvi se put ovdje objavljuje u autorovu prijevodu s hebrejskoga i aramejskog jezika na hrvatski jezik.

Ključne riječi: Biblija, David, Bat-Šeba, Urija, Midraš, Talmud, Tora.

\footnotetext{
* Izv. prof. dr. sc. Kotel Dadon, Sveučilišta u Zagrebu, Filozofski fakultet, Katedra za judaistiku; glavni rabin Židovske vjerske zajednice Bet Israel u Hrvatskoj; Ivana Lučića 3, HR-10000 Zagreb.
} 


\section{Uvod}

Veza Davida i Bat-Šebe opisana je u jednom je od najkompleksnijih tekstova u Bibliji. Kralj David, kralj i prorok, autor Psalama, jedan je od kamena temeljaca Usmene Tore, ${ }^{1}$ čovjek velike duhovnosti, ${ }^{2}$ koji je navodno počinio vrlo ozbiljne grijehe protiv Deset Božjih zapovijedi: »Ne ubij!«, »Ne učini preljuba!«, »Ne poželi žene bližnjega svoga« (Izl 20,13-14.17). ${ }^{3}$ Počinio je preljub s Bat-Šebom, udanom ženom te je ubio njezina supruga Uriju slanjem na prvu crtu bojišnice da bi Urija poginuo u bitki te da bi prikrio svoj prvi grijeh i, s vremenom, BatŠebu uzeo sebi za ženu. Može li to uistinu biti onaj isti David - pjesnik nježne duše i velike duhovne dubine, čovjek za kojega Biblija na raznim mjestima svjedoči da se uzda u Boga? Zar je takav čovjek sposoban za ovakva djela? Je li situacija doista bila takva kakvom se čini?

Nije ništa lakše shvatiti ni Božji odgovor na Davidova djela. Naizgled, umjesto kazne, primio je nagradu: prvo, okajao je svoj grijeh i nastavio biti Božji miljenik do vremena kraljevanja Salomona, sina kojeg je dobio s Bat-Šebom, do njegove krunidbe. No, usporedi li se Božji odgovor na Saulov grijeh pri postupanju s Amalekom (1 Sam 15), vidi se posve drukčija reakciju: Saulu je oduzeto kraljevstvo, a zatim su umrli i on i njegovi sinovi. Ta usporedba ostavlja dojam očite biblijske nepravde.

U rabinskoj literaturi Mudraci su na razne načine nastojali tumačiti ovu biblijsku epizodu. Neki su prihvatili sam tekst Biblije dok se drugi nisu složili $\mathrm{s}$ takvim postupkom i nastojali su ponuditi drukčije objašnjenje. Osim što se u članku razmatra taj slučaj te se nastoji analizirati tekst i pitanja koja on postavlja, također se pokušava odgovoriti i na druga pitanja te shvatiti biblijsku pripovijest na temelju rabinske literature.

\footnotetext{
${ }^{1}$ Usmena Tora - Nauk; prema tradiciji riječi kojima se Bog izravno objavio Mojsiju na brdu Sinaju; u užem smislu Tora šebihtav (pisana Tora, Petoknjižje, pet knjiga Mojsijevih); u širem smislu i Tora šebealpe (usmena Tora), usmena tradicija, propisi i tumačenja Tore, koju su naraštaji kao tradiciju prenosili sve do zapisivanja u Mišni i Talmudu. Vidi još u Kotel DaDON, Židovstvo. Život, teologija i filozofija, Zagreb, 2009, 488-495. Vidi još: Kotel DaDON, Pisana i Usmena Tora. Može li jedna bez druge? Nova prisutnost, 10 (2012) 3, 419-442; O Kralju Davidu kao jednom od nositelja usmene Tora vidi DaDon, Židovstvo..., 493.

${ }^{2}$ O stupnju duhovnosti kralja Davida vidi: Agnes E. DaDON, Kotel DaDON, Rođenje kralja Davida u mističnoj rabinskoj literature, Crkva u svijetu, 53 (2018) 4, 575-601; Babilonski Talmud (dalje: BT), Berahot 4a, 57b, Jeruzalem, Steinsaltzovo izd. 1999. (dalje: Steinsaltz); BT Baba Batra 17a, Bnei Brak, Vilnius - Machon Tevel, 1961. (dalje: Vilne); Jeruzalemski Talmud (JT), Venecija, 1523, Berahot 9,5.

3 Jure KAŠTELAN, Bonaventura DUDA (gl. ur.), Sveto pismo Staroga i Novoga zavjeta, Zagreb, Kršćanska sadašnjost, 2008. (dalje KS). U slučajevima kada taj prijevod koristi tetragram JHVH, autor ga zamjenjuju imenima Vječni, Gospodin, Svevišnji ili Gospod, jer u židovstvu nije dopušteno izgovarati Božje ime JHVH.
} 


\section{Biblijska pripovijest}

Pripovijest se nalazi u Drugoj knjizi o Samuelu, u 11. i 12. poglavlju. Čitajući te retke postajemo svjesni prilično problematične slike: Joab, komandant vojske, nalazi se usred rata protiv Amonaca, dok David uživa u svojoj palači. David se odmara od podneva do kasno uvečer, nakon što ustane šeće krovom svoje palače i s toga mjesta vidi prekrasnu ženu koja se kupa. Šalje sluge da doznaju tko je ona, a oni mu javljaju da je riječ o Bat-Šebi, supruzi Urije, vojnoga junaka. Bat-Šeba je dovedena u Davidovu kući i on liježe s njom, zajedno provode noć, a ujutro je pušta da se vrati kući. Što je točno David želio doznati? Saznao je da je udana žena, a ipak je legao s njom. Sve postaje još složenije kada Bat-Šeba shvaća da je trudna i to javlja Davidu. U nastojanju da prikrije što je učinio, David šalje poslanike Joabu s naredbom da što prije vrati Uriju iz rata u Jeruzalem. Namjerava ga poslati kući da bi i Urija legao sa svojom suprugom i pomislio da je začeto dijete njegovo. Ali, zbiva se neočekivano - Urija vrlo odlučno odbija poći kući jer smatra da ne zaslužuje takvu ugodu dok mu drugovi ginu u ratu. David se suzdržava i ne reagira na Urijino odbijanje, iako je time povrijeđena njegova kraljevska čast, nego ga ponovo pokušava poslati kući tako što ga opija. Urija ponovo odbija poći kući i ostaje u kraljevoj palači. Kada David shvati da nije uspio u pokušaju da prikrije posljedice svojega djela, odlučuje se na najgori mogući postupak - svoga vjernoga junaka šalje u smrt. Sam Urija nosi Joabu naredbu da ga se pošalje u smrt na prvoj crti bojišta. Joab izvršava Davidovu naredbu i šalje Uriju u smrt, a nakon toga David uzima Bat-Šebu za suprugu.

Prorok Natan dolazi kralju i pripovijeda mu priču o siromahu i bogatašu koji su živjeli u istome gradu. Siromah je imao ovcu za koju je bio vrlo vezan, podizao ju je u svojem domu zajedno sa svojom obitelji i bila je jedino što je imao. Jednoga dana bogatašu je došao gost te je bogataš od siromaha uzeo ovcu, zaklao je, skuhao i poslužio gostu. David bijesom odgovara na bezobrazluk bogataša, a prorok Natan mu objašnjava da se upravo on ponio kao bogataš u slučaju Urije i Bat-Šebe i da će stoga biti kažnjen. David shvaća i priznaje svoj grijeh.

\section{Kako su Mudraci tumačili vezu Davida i Bat-Šebe}

Analizirat će se dva glavna pitanja: prvo, pitanje odnosa Urije i Bat-Šebe da bi se provjerilo jesu li oni na bilo koji način vlastitim ponašanjem doprinijeli razvoju događanja, i drugo, središnje pitanje, je li David doista počinio preljub s Bat-ک̌ebom. 


\subsection{Urija i Bat-ک̌Seba}

Riječi »Trudna sam!« (2 Sam 11,5) jedine su Bat-Šebine riječi u cijelom događaju, a u odnosu na nju nameću se pitanja: Koja je bila njezina uloga u opisanom događaju? Je li ga i ona željela? Je li spremno surađivala?

$\mathrm{S}$ jedne strane, i Biblija i Mudraci, vide je u pozitivnom svjetlu. ${ }^{4} \mathrm{~S}$ druge strane, čini se da postoje nagovještaji da je i ona pokazala inicijativu u tim zbivanjima: »David (...) prošeta se po krovu svoje palače. Opazi s krova ženu gdje se kupa. Ta žena bijaše izvanredno lijepa (2 Sam 11,2). Zar se Bat-Šeba kupala na krovu?! RaDak objašnjava da je David s krova svoje kuće koja je bila najviša kuća u cijelome gradu vidio Bat-Šebu kako se kupa. Isto je jasno i u trenutku kada je David Uriju poslao u svoju kuću i ovako mu rekao: »Siđi u svoju kuću i operi svoje noge!« Očito, Urijina kuća nalazila se niz ulicu od Davidove kuće. Činjenica da se Bat-Šeba kupala unutar svojega doma ne ispričava njezinu neopreznost jer je jako dobro znala gdje je smještena njezina kuća te je znala da se u unutrašnjost njezine kuće može vidjeti s drugih povišenih mjesta. Redak »Kad je došla, leže on s njom, upravo kad se bila očistila od svoje nečistoće« (2 Sam 11,4) može se protumačiti dvostruko: prvo, Bat-Šeba se kupala u mikve ${ }^{5}$ te se tako očistila od nida, ${ }^{6}$ nečistoće koja je uzrokovana menstrualnim ciklusom, što potvrđuje da je David spavao s Bat-Šebom nakon što je bila nida. To jasno govori o tome da dijete ne može biti Urijino. Drugo tumačenje retka je da je Biblija željela naglasiti Davidovu nemoralnost (možda i nemoralnost Bat-Šebe), jer se ona očistila da bi bila sa svojim suprugom, a ne s nekim drugim čovjekom.

S druge strane, zašto bi Bat-Šeba poželjela biti s Davidom i napustiti muža koji je bio u ratu? Koliko je čvrsta bila veza između Bat-Šebe i Urije? U Bibliji nema dokaza da su Bat-Šeba i Urija imali djece. Postoje i izvori koji kažu da Urija nikada nije spavao sa svojom suprugom. ${ }^{7}$ Činjenično, to je moguće jer je Urija bio jedan od najistaknutijih Davidovih ratnika te je često odlazio na bojišta u ratove koji su ponekad trajali mnogo mjeseci $(1 \mathrm{Kr} 11,16)$. Stoga je Urija rijetko dolazio kući. Treba istaknuti da je prema Halahi ${ }^{8}$ muž obvezan prvu godinu braka provesti kod kuće sa suprugom te da mu je izrijekom zabranjeno

\footnotetext{
${ }^{4}$ Vidi: Rabin David KIMHI ili QIMHI (1160-1235), poznat je i po hebrejskom akronimu RaDaK, bio je srednjovjekovni rabin, komentator Biblije, filozof i proučavatelj gramatike. RaDakov komentar Biblije (Jerusalem, 1959, repr. Vienna, 1859), 1 Sam 11,2; vidi još: 1 Kr 1; BT Sanhedrin $70 b$ (Steinsaltz); Midraš Vajikra raba, Jeruzalem (reprint izdanja iz Vilniusa, 1878.) 12,5.

${ }^{5}$ Mikve - nakupina vode; nakupina prirodne vode (kišnica, otopljeni snijeg, led) koja služi obrednome očišćenju žene nakon stanja nida, te obrednome očišćenju preobraćenika obaju spolova pri primanju u židovstvo; more, izvor, rijeka ili umjetni bazen vode koji se djelomice puni kišnicom (vidi još u DaDon, Židovstvo..., 278-281).

${ }^{6} \mathrm{Nida}$ - udaljena; menstruirajuća žena, obredno nečista; zabranjeni su joj spolni odnosi s mužem. Tijekom sedam dana nakon prestanka menstruacije uranja u mikvu radi obrednoga očišćenja (vidi još u DaDon, Židovstvo..., 278).

7 Vidi Zohar I, 8 (Vilnius, 1923).

${ }^{8}$ Halaha - 1. pravni dio židovske vjerske književnosti; naziv dolazi od glagola halah (ići), jer idemo, tj. slijedimo židovsko pravo; 2. pojedina odredba iz sustava halahe.
} 
odlaziti u rat: »Kad se tko netom oženi, neka ne ide u vojsku; neka mu se ne dodjeljuje nikakva služba, nego, oslobođen, neka ostane kod kuće godinu dana da razveseljuje ženu koju je doveo« (Pnz 24,5; Pnz 20,7).

Tora shvaća izuzetnu važnost mogućnosti da novovjenčani par prvu godinu bračnoga života provede zajedno, gradeći svoj odnos i tome pridodaje toliko značenje da zabranjuje mužu da napusti ženu da bi otišao u rat, bez obzira na važnost borbe. Stoga Urija krši ovu zapovijed na najekstremniji način. Njegov fokus bio je na ratovanju, a ne na njegovoj mladoj supruzi. To bi također moglo objasniti i Urijino odbijanje Davidove naredbe da pođe kući te da bude sa svojom suprugom. Njegova odanost vojsci nadmašila je njegovu odanost supruzi. Nema nikakve sumnje da je takav stav mogao utjecati i na Bat-Šebine osjećaje prema njemu. Može se pretpostaviti i da je David, kao vrhovni komandant vojske i osoba odgovorna za svoje vojnike, osjećao krivicu što je indirektno i nenamjerno bio kriv za Urijino napuštanje Bat-Šebe time što je novopečenog mladoženju poslao na ratište.

Mudraci saznaju mnogo o Urijinu stanju i njegovu ponašanju na temelju razgovora s Davidom i osobito njegova odbijanja kraljeve ponude ili naredbe da ode kući i bude sa svojom ženom nakon što je toliko dugo bio odsutan, tj. na bojištu (2 Sam 11,8-11). Odlučnost i snaga kojom Urija govori u neskladu su sa suosjećajnim i nedužnim Davidovim pitanjem, barem na prvi pogled. Mudraci objašnjavaju da Urija nije samo odbio kraljevu naredbu da ode kući, nego je njegov govor bio vrlo arogantan i uvredljiv. ${ }^{9}$ Takvim riječima Urija kao da želi reći da Davidova naredba da napusti svoje vojnike na bojnome polju te se ode odmoriti i uživati u svojem domu (kako to David čini boravkom u jeruzalemskoj palači tijekom rata dok mu je vojska na bojištu), upućuje na to da David uživa u udobnosti palače, ne osjećajući bratstvo s ratnicima koji riskiraju živote u ratu.

Osim toga, Urija u nazočnosti kralja naziva svojeg zapovjednika Joaba »moj gospodar«. To Mudraci tumače kao znak pobune protiv kralja, a biblijski tekst to dvaput ističe, nazivajući kralja istom titulom »gospodar« (2 Sam 11,9.13). Takvim ponašanjem Urija Davidu pokazuje da je njegov pravi gospodar Joab te da su vojnici Joabovi, a ne Davidovi. Stoga David, koji šeće krovom u Jeruzalemu, ne bi trebao ni pokušavati voditi vojni pohod. Uistinu, slika Joaba kao središnje vojne osobe nije kontroverzna. No, Mudraci Talmuda govore nam o posebnom i komplementarnom odnosu Davida i Joaba:

»Rabin Abba bar Kahana kaže: Da nije bilo Davida, [koji je učio Toru], Joab ne bi uspješno vodio rat i da nije bilo vojne vještine Joaba, David ne bi mogao učiti Toru. Kako je pisano: 'David kraljevaše nad svim Izraelom, čineći pravo i pravicu svemu svome narodu. Joab, sin Sarvijin, zapovijedaše vojskom' (2 Sam 8,15-16). Zašto je pisano o Davidu: 'Čineći pravo i pravicu svemu svome narodu'? Mogao je tako činiti jer je 'Joab, sin Sarvijin, vodio vojsku' [pomažući mu i

\footnotetext{
9 Vidi: BT Kidušin 43a (Vilne).
} 
boreći se za njega]. A zašto ‘Joab, sin Sarvijin, zapovijedaše vojskom’? [Mogao je tako činiti] jer je 'David pravedno sudio cijelom svojem narodu.' ${ }^{10}$

Usprkos tome što su se David i Joab tako nadopunjavali, u slučaju Urije Midraš ${ }^{11}$ pripovijeda da je Joab izdao Davida jer nije čuvao tajnu o sadržaju poruke koju mu je David poslao o Urijinoj smrti:

»I sam znaš što mi je učinio Joab, sin Sarvijin, kako je učinio obojici vojskovođa Izraelovih: Abneru, sinu Nerovu, i Amasi, sinu Jeterovu, kad ih je ubio i time prolio krv u miru kao u ratu te omastio krvlju pojas oko bokova svojih i obuću na nogama svojim." (1 Kr 2,5). Što mu je učinio kada je David pisao Joabu: 'Postavite Uriju naprijed, gdje je najžešći boj, pa uzmaknite iza njega: neka bude pogođen i neka pogine!' (2 Sam 11,15), Joab je tako učinio i Urija je poginuo. Svi vojni komandanti došli su i željeli ubiti Joaba jer je Urija bio prvi među herojima, kao što je rečeno: 'Urija Hetit. Svega trideset i sedam.' (2 Sam 23,39). Kada je to Joab vidio, pokazao im je pismo koje je primio od Davida. ${ }^{12}$

Prema Midrašu, nakon Urijine smrti, vojni zapovjednici koji su bili Urijina braća po oružju, shvatili su da su okolnosti Urijine smrti bile čudne te su se pobunili. Zbog toga je Joab svojim vojnicima pokazao pismo koje mu je poslao David, a u kojemu je bila zapovijed da organizira Urijinu pogibiju. Time je Joab izdao Davidovo povjerenje i osobno ga strašno povrijedio. Zato je David u svojoj oporuci prije svoje smrti naložio svojemu sinu Salomonu da se pobrine da Joab ne umre spokojno.

Što se Urije tiče, doista je moguće objasniti da je Urija možda ovako odgovorio na Davidovo pitanje bez nakane da povrijedi kralja, jer bi se loše osjećao da je otišao kući dok mu prijatelji ratuju. Ipak, moguće je i da je noć prije spomenutoga razgovora s kraljem, dok je spavao u kraljevoj kući s drugim kraljevim slugama, od njih saznao da mu je tijekom njegova odsustva žena dovedena na dvor pred kralja jer, kako se vidi iz pripovijesti, mnogo je ljudi znalo za odnos između Davida i Bat-Šebe. David nije bio diskretan. Kraljevi sluge koji su spavali zajedno s Urijom u kraljevoj kući i vidjeli kako Bat-Šebu dovode kralju nekoliko dana prije Urijina povratka u Jeruzalem, povezali su ova dva događaja i ta je informacija nekako došla do Urije, bilo izravno ili neizravno. To je korijen njegove drske i ljutite reakcije prema kralju i zato je odbio vidjeti suprugu koja ga je, kako je vjerovao, izdala.

Urija, koji je u ratu bio voljan položiti život za svojega kralja, nije bio spreman obuzdati svoje osjećaje prema Davidu koji je, kako je on to doživio, uvrijedio i njega i njegovu ženu. No, moguće je da Bat-Šeba nije na isti način gledala na taj događaj (kako je prije objašnjeno). Nakon Urijinih grubih riječi David je bio povrijeđen do dna duše i prestao je gledati Uriju kao odana ratnika i brata po

\footnotetext{
${ }^{10}$ BT Sanhedrin 49b (Steinsaltz); s aram. prev. autor članka.

${ }^{11}$ Midraš - rabinska literatura tumačenje Tore; vidi još o Midrašu DaDon, Židovstvo..., 503-505.

${ }^{12}$ Midraš Bemidbar raba, Jeruzalem (reprint izdanja iz Vilniusa, 1878.) 23.13; s aram. prev. autor članka.
} 
oružju nego ga je promatrao kao čovjeka ovisna o osjećaju moći što ga donosi ratna pobjeda i kao plaćenika koji živi od mača.

Ipak, Biblija smatra čin Urijina ubojstva grijehom: "Zašto si prezreo Svevišnjega i učinio ono što je zlo u njegovim očima? Ubio si mačem Uriju Hetita, a njegovu si ženu uzeo za svoju ženu. Jest, njega si ubio mačem Amonaca« (2 Sam 12,9). David je zatim kažnjen: »Zato se neće nikada više okrenuti mač od tvoga doma...« (2 Sam 12,10). Čak i ako kažemo da je Urija morao umrijeti kao pobunjenik protiv kralja, ipak ga je David trebao poslati pred sud, umjesto da ga pošalje u smrt na bojnome polju. ${ }^{13}$ David je za takav postupak imao osoban motiv - Bat-Šeba je bila trudna s njim, nosila je njegovo dijete. Urijina presuda možda je u skladu sa zakonom, ali nije pravedna.

Geršonid $^{14}$ ide čak i dalje te korijen Davidova grijeha vidi u njegovu sebičnu ponašanju, on uživa u zadovoljstvima u vrijeme patnje naroda. Geršonid u Uriji vidi model ideje solidarnosti s bližnjim, zajednicom ili narodom kada se nađu u nevolji:

»Iz toga učimo da se čovjek ne smije okrenuti zadovoljstvu dok mu je susjed u nevolji. Vidimo da se sam Urija nije dao natjerati da ode kući i spava sa svojom ženom dok su Joab i cijeli Izrael bili u nevolji... i vidimo što se dogodilo Davidu zbog zla što si je dopustio zadovoljstvo u vrijeme nevolje - do razine na kojoj je poželio Bat-Šebu, iako je znao da je udana te je došao k njoj, a ona je zanijela; zbog toga je, pak, još sagriješio i nastojao da Uriju ubije mač Amonaca...« «15

\subsection{Je li David počinio preljub s Bat-Šebom?}

Na temelju biblijskih redaka (2 Sam 11,2-3), Davidova kasnijeg ponašanja i posljedica te noći (2 Sam 11,8-11), Gospodinova odgovora (2 Sam 11,27), Natanova proročanstva (2 Sam 12) i kazne kojom je David kažnjen (2 Sam 12,11-12),

${ }^{13}$ Vidi BT Šabat 56a (Steinsaltz) i BT Megila 14b (Steinsaltz). Postoji mišljenje da u slučaju izdaje kralj smije ubiti bez odluke suda. Vidi i Majmonid u Mišne Tora, Jeruzalem, 1974. (reprint varšavskog izdanja iz 1881.), Jad Ha-Hazaka = Mišne Tora (dalje: MT), Hilhot Melahim 3,8.

${ }^{14}$ Levi ben Geršon, rabi, skraćeno: Ralbag, zvani i Geršonid (Bagnols-sur-Ceze, Francuska, 1288-1344) - Jedan od velikih židovskih srednjovjekovnih filozofa, dobio je široko vjersko i znanstveno obrazovanje. Bavio se znanošću: medicinom, matematikom i astronomijom, ali i židovstvom, filozofijom i komentiranjem Tore i proročkih knjiga. Glavno filozofsko djelo mu je Milhamot Hašem (Ratovi Vječnoga). Premda znameniti filozof, uvidjevši koliko su Židovi zastranili odajući se filozofiji, dao je naglasak na istinsku vjeru i odmak od filozofije. Otkrio je novosti na području astronomije i izumio dva instrumenta za astronomsko promatranje, te na temelju svojih promatranja predložio alternativnu teoriju ptolemejskome astronomskom sustavu, nastojeći pomiriti stajališta astronoma i fizičara s vjerskim načelima, čime je utjecao na učene ljude svoga doba.

${ }^{15}$ Iz Geršonidovog komentara na Proroke, 2 Sam 21, na kraju gdje navodi sve dobre strane biblijskih zbivanja ove knjige, benefit br. 42, izdanje Mehokeke Lev Karinski, Jeruzalem, 1961; s heb. prev. autor članka; O zabrani Židovima da se prepuste užicima u vrijeme nevolje koja je zahvatila zajednicu vidi još u: Kotel DaDON, Duhovni otpor tijekom holokausta. Interpretacija izabranih primjera literature response, Crkva u svijetu, 51 (2016) 2, 203-234, 211. 
čini se da je David uistinu prekršio strogu zabranu preljuba, jer je izgubio nadzor nad samim sobom kad ga je zavela tjelesna požuda. S druge strane, postoje poteškoće koje proizilaze iz pretpostavke da je Bat-Šeba bila udana žena.

Prvo, David nije odmah legao s Bat-Šebom, nego se prije toga raspitao, poslao glasnike da saznaju tko je ona i kakav joj je bračni status. Takvo ponašanje nije tipično za osobu koja je izgubila nadzor nad svojim željama, jer se takva osoba najčešće ponaša nagonski, dok Davidov postupak ostavlja dostatno vremena za razmišljanje, prosuđivanje i nadzor.

Drugo, David ništa ne čini potajno, što bi ukazivalo na nedopuštenost čina. On šalje glasnike da Bat-Šebu dovedu u njegovu kuću kao da to sve namjerava učiniti javno. Glagol poslati - שלח pojavljuje se mnogo puta u ovoj propovijesti: ${ }^{16}$

»(1) Posla David Joaba i s njim svoje ljude i svega Izraela... (3) David je poslao ${ }^{17}$ da se propita za tu ženu... (4) Nato David posla glasnika da je dovedu k njemu. (5) Žena zatrudnje te posla ${ }^{18}$ Davidu poruku: 'Trudna sam!' (6) Tada David posla poruku Joabu: 'Pošalji k meni Uriju Hetita!' I Joab posla Uriju k Davidu... (12) Tada David reče Uriji: 'a sutra ću te poslati'. ${ }^{19}(18)$ potom Joab posla čovjeka i javi Davidu sve što se dogodilo u boju. (22) Glasnik... dođe k Davidu i pripovjedi mu sve što mu je poslao ${ }^{20}$ Joab. (27) A kad je prošlo vrijeme žalosti, posla David po nju i uze je u svoj dvor, i ona mu posta ženom...« (2 Sam 11).

David pet puta šalje glasnike, a i Bat-Šeba Davidu šalje poruku da je trudna. David šalje Joabu poruku da pošalje Uriju natrag, Joab šalje poruku Davidu i tako dalje. Sve zajedno, ovaj se glagol pojavljuje 12 puta u ovoj pripovijesti. Slanje glasnika, bilo da ih šalje kralj ili da netko drugi kralju šalje poruku preko glasnika, potpuno je prirodna stvar jer kralj nije obična osoba. No, korištenje osobitoga glagola u ovom kontekstu upućuje na to da je to vodeća riječ ${ }^{21}$ koja igra osobitu ulogu u objašnjenju središnje ideje. Doista, u ovom kontekstu vrlo intimnog ponašanja koje zahtijeva diskreciju, slanje glasnika može imati vrlo

\footnotetext{
${ }^{16}$ U nekim slučajevima u prijevodu Biblije Kršćanske sadašnjosti ovaj je glagol drukčije preveden zbog čega je smisao djelomično izgubljen. Vezano uz problem biblijskog prevođenja vidi: Kotel DaDON, Pisana i Usmena Tora. Može li jedna bez druge?, Nova prisutnost, 10 (2012) 3, 419442, bilj. 56 i 86; isti, Umjetna oplodnja u židovstvu, Nova prisutnost, 12 (2014) 1, 67-90, 86 bilj. 97; isti, Odnos poslodavca i zaposlenika u židovskom pravu, Nova prisutnost, 13 (2015) 3, 301-317, bilj. 14, 37; Agnes E. DaDON, Kotel DaDON, Salomonova presuda - jezična analiza i interpretacija (1 Kr 3, 16-28), Nova prisutnost, 15 (2017) 1, 47-64, bilj. 14, 20, 21, 24, 33; Kotel DaDON, Stav prema spašavanju života u židovskom zakonu. Milosrdni Samarijanac - ideal ili dužnost, moralna ili pravna obveza?, Nova prisutnost, 15 (2017) 3, 393-423, 凶bilj. 3 『i na drugim mjestima.

${ }^{17}$ Autor je preveo tako jer je u prijevodu KS-a riječ poslao prevedena s propita.

${ }^{18}$ Autor je preveo tako jer je u prijevodu KS-a riječ poslao prevedena s poruči.

${ }^{19}$ Autor je preveo tako jer je u prijevodu KS-a riječ poslao prevedena s otpustiti.

${ }^{20}$ Autor je preveo jer u KS prijevodu riječ poslao prevedena je naložio.

${ }^{21} \mathrm{Za}$ primjere vodećih riječi vidi $\mathrm{Br} 3,23 ; 25,8 ; 16,3.7 .9$; Pnz 26,1-11; O vodećoj riječi vidi: Martin BUBER, Darko šel MIKRA, Ijunim bidfuse signon ba Tanah, Jeruzalem, Mosad Bijalik, 1978, 284; vidi još u Agnes E. DaDON, Kotel DaDON, Značenje i prednost proučavanja židovske Biblije na biblijskom hebrejskom jeziku, Nova prisutnost, 17 (2019) 2, 369-393, 388.
} 
nezgodne posljedice jer događaj više nije zaštićen diskrecijom stoga što ga sad glasnici mogu učiniti javno poznatim.

Treće, ako je Bat-Šeba doista udana žena, onda se na koncu pojavljuje i problem izvanbračnog odnosa. Prema židovskom zakonu, u slučaju preljuba s udanom ženom, žena se mora razvesti od muža i ne smije se udati za onoga s kojim je počinila preljub. »Kako je zabranjena svojemu mužu, tako je zabranjena i svojem ljubavniku. $\ll^{22}$ Dakle, da je Bat-Šeba doista bila udana žena, David se njome ne bi smio oženiti. No, umjesto toga, nakon što je u potpunosti priznao svoj grijeh i primio kaznu po riječima proroka te se u potpunosti pokajao, od njega se nije tražilo da ostavi Bat-Šebu. Dapače, Bog je volio Salomona, njezina sina, i prorok Natan naziva ga Jedidja - prijatelj Svevišnjeg (2 Sam 12,24) te se čak bori da Salomon zauzme Davidovo prijestolje (1 Kr 1,11-27).

Jedinstveno rješenje ovih triju poteškoća moguće je jedino ako se pretpostavi da Bat-Šeba nije bila udana kada je imala spolni odnos s Davidom, barem ne formalno. Temelj takvom objašnjenju pronalazi se u mišljenju nekih Mudraca u Talmudu koje baca drukčije svjetlo na pripovijest. Pitanje je ovako izloženo u Talmudu:

»Rabin Samuel bar Nahmani rekao je u ime rabina Jonatana: Svaki koji kaže da je David sagriješio s Bat-Šebom jednostavno griješi jer je rečeno: 'David je imao uspjeha na svim svojim putovima jer Svevišnji bijaše s njim' (1 Sam 18,14). Je li moguće da je njegove ruke okaljao grijeh, a da je božanska prisutnost svejedno bila s njime? Ali, kako onda utvrditi značenje prijekora proroka Natana: 'Zašto si prezreo Svevišnjega i učinio ono što je zlo u njegovim očima? Ubio si mačem Uriju Hetita, a njegovu si ženu uzeo za svoju ženu. Jest, njega si ubio mačem Amonaca' (2 Sam 12,9), što upućuje na to da je David sagriješio? «23

Rabin Samuel bar Nahmani tvrdi da je nezamislivo da je David sagriješio jer je Bog bio s njim. S druge strane, kako je moguće reći da nije sagriješio nakon što se pročita kritika proroka Natana?

»David je želio učiniti zlo i imati odnos s Bat-Šebom dok je ona još bila udana za Uriju, ali to nije učinio. Rav je rekao: Rabin [Juda HaNasi], ${ }^{24}$ koji je potomak

\footnotetext{
${ }^{22}$ Vidi: Mišna Sota 5,2 vidi još: BT Ketubot 9a (Vilne); MT Sota 2,12; Karo R. Josef (1485-1575) Šulhan Aruh, Jeruzalem Ketuvim (1992); ŠA Even HaEzer 178, 17.

${ }^{23}$ Vidi BT Šabat 56a (Steinsaltz); s aram. prev. autor članka.

${ }^{24}$ Rabin Juda HaNasi, Rabi (120. - Bet Śearim, Izrael, 220.) - pripadnik posljednjeg naraštaja tanaita, izraelski nasi (knez) 140.-200. godine p. n. e. Nazivan je ukratko Rabi (moj učitelj) ili Rabenu hakadoš (naš sveti učitelj). Bio je sin i nasljednik rabana Šimona ben Gamaliela Drugog, sedmi naraštaj od Hilela Starog, koji je potjecao od kralja Davida. Kao sposoban vođa, postigao je dobre odnose između Rimljana i židovske vlasti, a time slobodu stvaranja za židovske učenjake, te su odnosi Rimljana i židovskog stanovništva bili bolji nego ikada od rušenja drugoga Hrama. Bio je blizak s carem. Svojim osobitim sposobnostima za vođenje, nakon neuspjeha ustanka bar Kohve uspio je uspraviti narod i u materijalnom smislu, ojačavajući židovsko vlasništvo nad zemljom u Izraelu i poreznim olakšicama, i u duhovnom smislu. Poticao je duhovno stvaralaštvo židovskih učenjaka vlastitom teškom zadaćom: zapisivanjem i uređivanjem usmene Tore - Mišne, prvog i najvažnijeg književno-halahičkog djela nakon Biblije. Većinu života proveo je u Bet Šearimu u Galileji, pred kraj života boravio u Ciporiju. O
} 
[kuće] Davida, objašnjava ovaj redak u Davidovu korist. ${ }^{25}$ [Što se tiče onoga što je pisano]: 'Zašto si prezreo zapovijed Božju i počinio zlo?' Rabin [Juda HaNasi] je rekao: Ovo zlo [koje se spominje u vezi s Davidom] drukčije je od svih drugih zala u Tori, ovako je pisano: I učinio je zlo, a ovdje je zapisano: Činiti zlo. [Ova jedinstvena fraza ukazuje na to da je David] namjeravao počiniti zlo, ali u stvarnosti ga ipak nije počinio. [Kako je pisano]: 'Ubio si mačem Uriju Hetita' (2 Sam 12,9), znači da si mu mogao suditi pred Sinedrijem ${ }^{26}$ [kao čovjeku koji je kriv za izdaju kralja], a ti mu nisi sudio na takav način. [Umjesto toga, dao si ga pogubiti na način koji je odstupao od općeprihvaćenih načela suda]. Što se tiče retka: 'a njegovu si ženu ${ }^{27}$ uzeo za svoju ženu' (2 Sam 12,9) to znači da imaš pravo oženiti se njome [jer je po zakonu Bat-Šeba već bila razvedena od Urije]. Kako je rekao rabin Samuel bar Naḥmani u ime rabina Jonatana: Svaki muškarac, koji krene u rat koji vodi Davidova kraljevska kuća, piše svojoj ženi ispravu o razvodu... Vezano uz ono što je pisano: 'Ubio si mačem Uriju Hetita, a njegovu si ženu uzeo za svoju ženu. Jest, njega si ubio mačem Amonaca' (2 Sam 12,9) to znači: 'Isto kao što nisi kažnjen za vojnike koje je ubio mač Amonaca tijekom rata, tako nisi kažnjen ni za smrt Urije Hetita. ${ }^{28}$ Zašto [David nije bio odgovoran za smrt Urije]? Zato što je Urija bio izdajnik prijestolja. Zato što je Davidu rekao: 'Moj gospodar Joab i straža moga gospodara borave na otvorenu polju' (2 Sam 11,11). [U nazočnosti kralja, nikoga drugog ne smije se nazivati gospodarem. Tako činiti znači počiniti izdaju.] $\ll^{29}$

Navedeni odjeljak Talmuda nastoji odgovoriti na prvo pitanje postavljeno u ovome članku, kako je moguće da je kralj David, čovjek duha i čovjek kojega je Bog toliko volio, počinio tako težak grijeh preljuba s udanom ženom. Talmud skreće pozornost na postojanje osobita običaja u vrijeme vladanja kralja

njemu je rečeno: »Tora i veličina (bogatstvo i slava) na jednome mjestu« (BT Gitin 59a Vilne) te: »Otkad je umro Rabi, nema (takve) skrušnosti i straha pred grijehom« (BT Sota 49b, Vilne; BT Ketubot 103b, Vilne).

${ }^{25}$ Ova talmudska bilješka stavlja rabina Judu HaNasija, potomka kralja Davida, u nezavidan položaj. Ipak, teško je sa sigurnošću odrediti je li Ravov komentar mišljen kao pohvala ili kritika rabina Jude HaNasija koji je pokušao Davida sagledati u povoljnom svjetlu radi vlastitog podrijetla.

${ }^{26}$ Sinedrij ili Vijeće staraca; izvor riječi je grčki (synédrion); židovsko legislativno tijelo i vrhovni sud u doba drugoga Hrama, od hašmonejskoga doba (165. pr. n. e.) do 425. n. e.; od gubitka neovisnosti 70. n. e. do kraja svoga djelovanja preuzima od kralja zastupanje zemlje pred rimskim i bizantskim vlastima; sastojao se od 71 člana, što je spomen na Mojsija i 70 staraca. Predsjednik Sanhedrina bio bi i vođa naraštaja, najmudriji čovjek svoga doba, poput zamjenika na Mojsijevom mjestu u svakome naraštaju. Sanhedrin je vodio predmete koji su imali utjecaj na sav židovski narod: imenovanje kralja, imenovanje Maloga Sanhedrina (23 suca u svakome gradu i plemenu), zakone o lažnim prorocima, teorijski slučajevi kada bi Veliki svećenik počinio zločin koji se kažnjava smrću, proširivanje granice grada Jeruzalema, te izlazak u rat kada nije bila obveza, i slično. Sanhedrin je zasjedao u Hramu dok je postojao, a 40 godina prije rušenja premješten je, te se selio kroz 10 različitih mjesta, od kojih je posljednje bilo Tiberijas. Tradicijski se smatra da će se u mesijanskome dobu Sanhedrin vratiti u Tiberijas, a zatim u Hram (vidi još u DaDon, Židovstvo..., 544-554.

${ }^{27}$ Glagol לקח - uzeti, u smislu u kojem je ovdje uporabljen, označava brak; vidi Pnz 24, 1; BT Kidušin 2a, 4b (Vilne).

${ }^{28}$ Vidi BT Šabat 56a (Steinsaltz) te BT Ketubot 9a (Vilne).

${ }^{29}$ Vidi BT Šabat 56a (Steinsaltz); s aram. prev. autor članka. 
Davida - njegovi vojnici običavali su svojim suprugama dati $g e t,,^{30}$ dokument o razvodu braka prije nego li bi otišli u bitku. ${ }^{31}$ Takav razvod bio je uvjetni get, ${ }^{32}$ razvod koji postaje valjan samo pod posebnim uvjetima. Uvjet koji je morao biti zadovoljen kako bi takav razvod postao valjan bio je da je muž nestao u bitci. Ako bi se to dogodilo, žena je bila razvedena takvim getom, te je tako dobila mogućnost ponovne udaje, a uklonjena je opasnost da žena postane aguna. ${ }^{33}$ Osim toga, ako je muž umro, a da za sobom nije ostavio potomstvo, ovakvim getom žena je pošteđena jibuma ${ }^{34}$ ili halica..$^{35}$ Takvim uvjetnim getom najčešće su se služili muškarci koji su odlazili na opasna putovanja i osobito oni koji su se spremali u rat. ${ }^{36}$

Postoji neslaganje među Mudracima o statusu žene koja je dobila uvjetni get, a vezano je uz trenutak u kojem se ženu počinje smatrati razvedenom. Smatra li se ona razvedenom od trenutka kada je primila get ili će postati razvedenom tek poslije smrti muža? ${ }^{37}$ Ova je kontroverza važna i ima izravan utjecaj na slučaj Davida i Bat-Šebe, jer se pripovijest dogodila prije Urijine smrti. Stoga se postavlja pitanje treba li se Bat-Šebu u vrijeme događaja s Davidom, dok je Urija još bio živ, smatrati razvedenom ili udanom ženom? Valja naglasiti da, ako se slijedi mišljenje da je žena koja je dobila uvjetni get još uvijek udana, od takvog uvjetnog geta ne bi bilo koristi jer bi se Bat-Šeba i dalje smatrala udanom. ${ }^{38}$

${ }^{30}$ Get - dokument o rastavi braka kojega muž daje ženi, napisan je na pergameni, a potpisuju ga dvojica svjedoka (vidi još u DaDon, Zidovstvo..., 449-451.

${ }^{31}$ Talmud objašnjava da je ovakva praksa započela ranije, tijekom vladanja kralja Saula. Jišaj, Davidov otac, naredio mu je da posjeti unovačenu braću u vojsci kralja Saula koja se borila u Filistejskom ratu. Iz toga Mudraci uče: »Kako je rečeno: 'A ovih deset sireva odnesi njihovu tisućniku. Propitaj se za zdravlje svoje braće i donesi mi njihov zalog [arubatam]' (1 Sam 17,18). (KS prijevod: 'Donesi od njih znak da si izvršio nalog!') Koje je značenje riječi arubatam? Rav Yosef je naučavao: Odnosi se na stvari koje se dijele [heb. haméoravim = miješano] između njega [supruga] i nje [supruge], tj. 'brak'« (BT Šabat 56a - Steinsaltz). Redak bi trebalo čitati: »Uzmi dokument o razvodu koji određuje status odnosa između muža i žene«, jer očito, bilo je uobičajeno da muževi koji se bore u ratu ženama pošalju uvjetni get.

${ }^{32}$ Više o Uvjetnom getu vidi još u DaDon, Židovstvo..., 450.

${ }^{33}$ Aguna - ostavljenica, žena koju je muž ostavio vezana je i ne može se udati dok se ne razvede i muž joj dade get, dokument o rastavi (vidi još u DaDon, Židovstvo..., 450).

${ }^{34}$ Jibum - djeverski ili leviratski brak; vjerska obveza iz Tore da se muškarac oženi udovicom svoga brata, ako oni u braku nisu imali djece (vidi još u DaDon, Židovstvo..., 450).

${ }^{35}$ Halica - izuvanje, obred ukidanja obveze da javam (brat muškarca koji je umro bez djece) i jevama (udovica takvoga supruga) stupe u brak; provodi ga udovica simboličnim izuvanjem obuće s jedne djeverove noge (vidi još u DaDon, Židovstvo..., 450).

${ }^{36}$ U Izraelu je postojao prijedlog da svaki oženjeni vojnik, koji sudjeluje u bitki, rabinatu dostavi takav uvjetni get, a rabinat bi proglasio razvod valjanim samo u slučaju da taj vojnik nestane u bitki. Prijedlog je odbio rabin Šlomo Goren, tadašnji glavni rabin Izraelskih obrambenih snaga, i to iz halahičkih razloga, ali uglavnom stoga što se bojao negativnog utjecaja koji bi takav potez imao na moral vojnika (vidi Rabin Šlomo GOREN, Responsa Mešiv Milhama, Jeruzalem, Hajidra Raba, 1984, 14).

${ }^{37}$ Vidi: BT Gitin 43b (Steinsaltz), BT Šabat 56a (Steinsaltz), BT Ketubot 9a (Vilne) i BT Baba Mecia 59a (Vilne).

${ }^{38}$ Vidi: Rabi Juda BT Gitin 73a (Vilne). 
Bilo kako bilo, rabin Juda HaNasi uzima iz govora proroka Natana redak koji najteže optužuje Davida: »Zašto si prezreo Svevišnjega i učinio ono što je zlo u njegovim očima? Ubio si mačem Uriju Hetita, a njegovu si ženu uzeo za svoju ženu. Jest, njega si ubio mačem Amonaca« (2 Sam 12,9), i tumači ga, frazu po frazu da bi Davida oslobodio najtežih aspekata njegova grijeha. Rabin iznosi dvije tvrdnje o dvama Davidovim grijesima: prvo, David nije sagriješio s udanom ženom jer je Urija, kao i svaki drugi vojnik u Davidovoj vojsci, svojoj ženi dao get; drugo, Urija je morao umrijeti zbog pobune protiv kralja pa David nije ubio nedužna čovjeka. Ipak, Talmud i dalje otvoreno kritizira Davida zato što je, umjesto da spor riješi sudom, Uriju poslao u smrt.

Čak i ako se prihvati mišljenje rabina Jude HaNasija da David formalno nije počinio preljub, ostaje činjenica da je moralno sagriješio. Nema sumnje da je Bat-Šebin muž, iako je bila službeno razvedena, vjerovao da će mu žena ostati vjerna. Jednako tako, i Rašba ${ }^{39}$ tvrdi da je prorok kritizirao Davida zato što, iako je muž dao supruzi ovakav uvjetni razvod, to je učinio da bi joj pomogao u slučaju vlastite smrti, ali nije stavljajući potpis na taj dokument presjekao emotivne veze s njom..$^{40}$ Stoga se čini da Mudraci nisu mogli u potpunosti osloboditi Davida od odgovornosti za ozbiljan prijestup koji je počinio.

S druge strane, postoji i drukčije mišljenje Mudraca prema kojem je David počinio grijeh preljuba s Bat-Šebom, jer je već opisani odjeljak iz Talmuda u kontradikciji s jednostavnim tekstualnim značenjem redaka koji opisuju Davida i Bat-Šebu. Pri kraju toga odjeljka nalazi se dodatak iz kojega se može pretpostaviti da je David sagriješio u takvome odnosu:

»Rav je rekao: Kada se preispituje pitanje o Davidu, postaje jasno da on tijekom svojega života nije počinio niti jedan grijeh, osim onoga s Urijom. Kako je pisano: 'Jer je David činio sve što je pravo u očima Svevišnjega i za svega svoga života nije odstupio ni od čega što mu je zapovjedio, osim onog što je učinio Uriji Hetitu' $(1 \mathrm{Kr} 15,5) . \ll^{41}$

Ali, glavni izvor na koji se pozivaju Mudraci, a koji jasno pretpostavlja da je Bat-Šeba doista bila udana žena, nalazi se na drugome mjestu u Talmudu. Taj izvor krivnju i odgovornost za počinjeni grijeh stavlja na Davida, koji je bio toliko samouvjeren i tako siguran da neće sagriješiti da je zatražio od Boga da ga preispita. Kada je Bog to i učinio, David je pao na testu:

\footnotetext{
${ }^{39}$ Rašba - Šelomo ben Avraham Aderet, rabi, skraćeno: Rašba (Barcelona 1235-1310) - Znameniti sefardski rabin. U mladosti se počeo baviti trgovinom, ali se povukao, te je postao vođa ješive i rabin Barcelone tijekom više od 40 godina. Upućivali su mu upite iz svih krajeva židovstva: Španjolske, Portugala, Francuske, sjeverne Afrike, Njemačke, Turske, Italije i Izraela, na koja je on napisao više od deset tisuća odgovora, koji su kasnije poslužili kao temelj za halahičke knjige, poput Šulhan aruha. Tisuće odgovora je objavljeno, ali još tisuće čekaju objavljivanje. Učenik rabenu Jone Gerondija i Rambana. Napisao je i komentar na Talmud te nekoliko halahičkih knjiga. Veliko znanje iz rimskoga prava, mjesnoga prava i ekonomije mnogo mu je pomoglo u vođenju židovske zajednice u Španjolskoj.

${ }^{40}$ Rašba in BT Ketubot 9b, paragraf »Kol Hajoce«.

${ }^{41}$ Vidi BT Šabat 56a (Steinsaltz); s aram. prev. autor članka.
} 
»Rav Juda kaže da je Rav rekao: Čovjek nikada ne bi trebao sam sebe podvrgnuti kušnji, kako je to David, kralj Izraela, učinio i posrnuo. David je rekao pred Bogom: Gospodaru svemira, zašto se u molitvi govori: Bože Abrahama, Bože Izaka i Bože Jakova, a ne govori se Bože Davida? Bog je odgovorio Davidu: Svi su oni bili podvrgnuti kušnji preda mnom, a ti nisi bio podvrgnut kušnji preda mnom. David mu reče: Ispitaj me i podvrgni me kušnji kako je rečeno: 'Ispitaj me, Svevišnji, iskušaj me, istraži mi bubrege i srce' (Ps 26,2). Bog mu je rekao: 'Podvrgnut ću te kušnji i tvoje će iskušenje biti [kakvo nije bilo za praoce], jer njih nisam unaprijed obavijestio o naravi kušnje, a tebe obavještavam da ću te podvrgnuti kušnji koja će uključivati pitanje [udane žene, s kojom] je odnos zabranjen.' Odmah zatim pisano je: 'A jednoga dana predvečer usta David sa svoje postelje i prošeta se po krovu svoje palače' (2 Sam 11,2). David reče: Bože, Gospodaru svemira, oprosti mi taj moj grijeh. Bog mu odgovori: Već je suđeno da tvoj sin Salomon u svojoj mudrosti kaže: 'Može li tko nositi oganj u njedrima, a da mu se odjeća ne upali? Može li tko hoditi po živom ugljevlju, a svojih nogu da ne ožeže? Tako biva onomu tko ide k ženi svoga bližnjega: neće ostati bez kazne tko god se nje dotakne' (Izr 6,27-29). David mu reče: 'Hoće li taj čovjek, David, biti protjeran za svoj prijestup, zar mu nema pomoći?' Bog odgovori Davidu: 'Uzmi na sebe muke [i to će biti okajanje za tvoje grijehe].' On je na sebe uzeo muke. ${ }^{42}$

Prema židovskom misticizmu, ${ }^{43}$ Bat-Šeba je bila suđena Davidu. Zohar to tumači iz činjenice da prorok Bat-Šebu naziva »Davidovom ženom《: »Potom David utješi svoju ženu Bat-Šebu« (2 Sam 12,24). Mudraci poučavaju:

»Rava je poučavao: Koje je značenje toga što je pisano: 'Jer umalo ne propadoh [lecela - heb. znači i rebra], i moja je bol svagda preda mnom' (Ps 38,18)? BatŠeba, kći Eliama, bila je smatrana prikladnom za Davida još od šestoga dana stvaranja. [Rava tumači da se izraz lecela odnosi na Evu koja je uzeta iz Adamova boka, prvog čovjeka, te objašnjava da je Bat-Šeba bila suđena Davidu baš kao što je i Eva bila suđena Adamu]. No, k njemu je došla kroz bol.«44

Bat-Šeba i David nisu jedini slučaj »bolnoga puta«, jer u dinastiji kralja Davida ima puno bolnih bračnih odnosa. ${ }^{45}$ Stoga se može zaključiti da se u rabinskoj literaturi razlikuju dva glavna stava vezana uz Davidov grijeh, onaj koji nastoji umanjiti Davidov grijeh te onaj koji taj grijeh prikazuje još i gorim nego što bi se moglo iščitati iz biblijske pripovijesti.

\footnotetext{
${ }^{42}$ BT Sanhedrin 107a (Steinsaltz); s aram. prev. autor članka.

${ }^{43}$ Zohar Mišpatim 106b.

${ }^{44}$ BT Sanhedrin 107a (Steinsaltz); vidi i BT Avoda Zara 4a (Vilne); s aram. prev. autor članka.

${ }^{45}$ Usp. DaDon, DaDon, Rodenje kralja Davida..., 598-599.
} 


\section{Kazna}

David je kažnjen dvjema kaznama. Jedna od njih potekla je iz njegovih usta, a druga od proroka.

\subsection{Davidova prva kazna}

»Tada David planu žestokim gnjevom na toga čovjeka i reče Natanu: 'Tako mi živog Svevišnjega, smrt je zaslužio čovjek koji je to učinio! Četverostruko će naknaditi ovcu zato što je učinio to djelo i što nije znao milosrđa!'« (2 Sam 12,5-6).

Svevišnji ga nije kaznio smrtnom kaznom jer se potpuno pokajao: »Tada David reče Natanu: 'Sagriješio sam protiv Svevišnjega!' A Natan odvrati Davidu: 'Svevišnji ti oprašta tvoj grijeh: nećeš umrijeti'« (2 Sam 12,13). David nastavlja određivati četverostruku kaznu bogatašu - Mudraci u Talmudu ${ }^{46}$ objašnjavaju da je David bogatašu koji je siromahu oduzeo ovcu odredio kaznu kojom Tora kažnjava pljačkaša koji je ukrao i zaklao ovce svojega bližnjeg, četverostruko plaćanje: »Tko ukrade goveče ili marvinče od sitne stoke, pa bilo da ga zakolje, bilo da ga proda, onda za jedno goveče neka se vrati petero goveda, a za malo marvinče četvero marvinčadi« (Izl 21,37). I doista, David je platio s četvero svoje djece koja su umrla: djetetom Bat-Šebe, Tamarom, ${ }^{47}$ Amnonom i Abšalomom. Midraš objašnjava da je David kažnjen ne četiri puta, nego četiri puta četiri:

»Pisano je: 'Četverostruko će nadoknaditi ovcu zato što je učinio to djelo i što nije znao milosrđa!' (2 Sam 12,6). Rabin Juda bar Hanina je rekao: 'Sveti, Blagoslovljeni, rekao je Davidu: Jednom si počinio preljub; $k$ tebi će doći šesnaest preljubnica. Ubio si jednom, $k$ tebi će doći šesnaestero ubijenih (što je značenje riječi arba'tajim), četiri puta četiri.'«8

\subsection{Davidova druga kazna:}

Druga kazna bila je kazna proroka u ime Boga:

»Zato se neće nikada više okrenuti mač od tvoga doma, jer si me prezreo i jer si uzeo ženu Urije Hetita da ti bude žena. Ovako govori Svevišnji: 'Evo ja ću podići na te zlo iz tvoga doma. Uzet ću tvoje žene ispred tvojih očiju i dat ću ih tvome bližnjemu, koji će spavati s tvojim ženama na vidiku ovome suncu'« (2 Sam 12,10-11).

\footnotetext{
${ }^{46}$ Vidi BT Joma 22a (Steinsaltz).

${ }^{47}$ Geršonid objašnjava da Tamara nije dio te četvorke, nego da je riječ o Adoniji, sinu Hagitinom (usp. 2 Sam 12,7).

${ }^{48}$ Midraš Tehillim (Shochar Tov) mizmor 3,4; Buber izdanja Vilnus, 1891, 19a-b; s heb. prev. autor članka.
} 
U toj se kazni prepoznaje slavni božanski način biblijskih kazni: »mjeru $z a$ mjeru - מידה כנגד מידה najosjetljiviji - u njegovu obitelj. Veza Davida i Bat-Šebe jako je utjecala na krug ljudi koji su Davidu bili najbliži, na njegovu djecu i žene. Teško je ne uočiti poveznicu između odnosa Amnona i Tamare te odnosa Davida i Bat-Šebe. Može se objasniti da se Amnon usudio silovati Tamaru jer je znao za grijeh svoga oca koji je počinio s Bat-Šebom, i smatrao je da njegov otac nema moralne snage da ga kritizira, pa je s Tamarom učinio što je želio. Doista, »kad je kralj David čuo sve što se dogodilo, vrlo se razgnjevi« (2 Sam 13,21), ali Amnonu nije učinio ništa. S druge strane, Abšalom, brat Tamarin, vidio je da njegov otac nije učinio ništa te je stoga uzeo zakon u vlastite ruke i sam proveo pravdu te osvetio silovanje sestre tako što je ubio Amnona.

David je nastavio primati udarce, ovoga puta od ljudi koji su mu bili vrlo bliski, na primjer, od najbližeg savjetnika Ahitofela. Ahitofel je bio izuzetno mudar čovjek. Biblija o njemu ovako svjedoči: »A savjet što bi ga dao Ahitofel $\mathrm{u}$ ono vrijeme, vrijedio je kao odgovor Božji; toliko je vrijedio svaki Ahitofelov savjet i kod Davida i kod Abšaloma« (2 Sam 16,23).

Ahitofela opisuje i Mišna ${ }^{50}$ kao Davidova rabina te kaže da ga je David vrlo poštovao. ${ }^{51}$ Ahitofelov sin Eliam bio je jedan od Davidovih junaka (2 Sam 23,34), a Bat-Šeba je bila Eliamova kći. Dakle, Bat-Šeba je bila Ahitofelova unuka. ${ }^{52}$ Ahitofelova osveta ${ }^{53}$ bila je brza. Kada se Abšalom pobunio, Ahitofel je stao uz njega te je Abšalomu savjetovao da kao znak osvete za zločin počinjen pro-

\footnotetext{
${ }^{49}$ Mjera za mjeru je moralno i zakonsko načelo koje se smatra temeljnim za razumijevanje biblijskog učenja. Bit toga načela je da se Bog ponaša prema ljudima onako kako se i oni ponašaju te da prašta onima koji se kaju. Izvor te fraze nalazi se u Talmudu: »To se temelji na onome što rabin Samuel bar Naḥmani kaže da je rekao rabin Jonatan: Otkuda učimo da sve što dobivamo od Presvetoga, Blagoslovljenog, dobivamo po načelu mjera za mjeru? To učimo iz retka, kako je rečeno [vezano uz opsadu Jeruzalema]: 'Elizej reče tada: Čuj riječ Svevišnjega! Ovako veli Svevišnji: Sutra će u ovo doba na vratima Samarije biti mjera finoga brašna za šekel, a dvije mjere ječmenog brašna za šekel' « (2 Kr 7,1). I pisano je: »Dvorjanik, o čiju se ruku kralj oslanjao, odgovori čovjeku Božjemu: 'I kad bi Svevišnji načinio okna na nebu, bi li to moglo biti?' A Elizej odgovori: 'Vidjet ćeš svojim očima, ali nećeš jesti' $(2 \mathrm{Kr} 7,2)$ « (BT Sanhedrin 109a, Steinsaltz). Za primjere mjere za mjeru u Bibliji vidi: Post 3,1-15; 4,11-12; 6,12-13; 9,6; Izl 4,22-23; 21,22-27; Lev 24,17-20; Pnz 19;24,16; 1 Kr 20,35-43; 2 Kr 21,11-12; Izr 17,13. Za više objašnjenja vidi: Kotel DaDON, Biblijska kazna. Oko za oko (lzl 21,22-25; Lev 24,17-22; Pnz 19,16-21), odmazda ili naknada štete?, Obnovljeni život, 67 (2012) 4, 441-457.

${ }^{50}$ Mišna - ponavljanje, učenje; 1 . temeljna literatura židovskoga prava usmene Tore; uredio ju je rabi Juda HaNasi (188. godine) i ima šest glavnih dijelova (Šiša sidre Mišna); najveći i najvažniji izvor Halahe (židovskoga prava) iz doba tanaita, corpus juris Halahe; 2. svaka odredba u sustavu Mišne (usp. DaDon, Židovstvo..., 512).

${ }^{51}$ Mišna Avot 6,3.

${ }^{52}$ Prema stihovima, Bat-Šeba je unuka Ahitofela; usp. 11,3 i 23,34 te vidi BT Sanhedrin 69a (Steinsaltz).

${ }^{53}$ Moramo primijetiti da je David volio Bat-Šebu i njezinog sina Salomona, pa se čini da Ahitofel očito nije imao stvarnoga razloga toliko mrziti Davida. Pristajanjem uz Abšaloma koji se pobunio protiv Davida, Ahitofel uistinu dovodi u opasnost šansu da njegov praunuk Salomon postane kralj.
} 
tiv njegove unuke, ima intimne odnose s priležnicama ${ }^{54}$ svojega oca na onom istom krovu na kojem je David ugledao Bat-Šebu. ${ }^{55}$ Time je ispunjeno Natanovo proroštvo: »Uzet ću tvoje žene ispred tvojih očiju i dat ću ih tvome bližnjemu, koji će spavati s tvojim ženama na vidiku ovome suncu. Ti si doduše radio tajno, ali ja ću ovu prijetnju izvršiti pred svim Izraelom i pred ovim suncem!« (2 Sam 12,11-12).

David je povrijedio odnose sa svojom obitelji te su time i odnosi među ostalim članovima njegove obitelji bili povrijeđeni. Talmud pripovijeda da je David zamolio Boga da mu oprosti te da je, da bi zaslužio oprost, morao pristati na različite muke, s čime se složio. Prihvatio je muku gube na sebi na šest mjeseci, Božji duh ga je napustio, a napustio ga je i Sanhedrin. ${ }^{56}$ Talmud također pokazuje da je, kao dio kazne za svoj grijeh, David bio zlostavljan:

»Rava je naučavao: Koje je značenje onoga što je pisano: 'A sada kad posrnuh ja, oni se raduju, skupiše se protiv mene da udare iznenada, i bez prestanka oni me razdiru [dammu]' (Ps 35,15)? David je rekao pred Presvetim, Blagoslovljenim: Gospodaru svemira, tebi je znano i otkriveno da kada bi moji neprijatelji otrgnuli moje meso, moja krv [dami] ne bi potekla na zemlju [zbog pretjeranog posta] (2 Sam 12,16-17)'. David je nastavio: Osim toga, moji neprijatelji me muče toliko da u vrijeme kada javno proučavaju zakone četiriju sudskih smrtnih presuda, prekidaju svoje učenje i kažu mi: Davide, što se tiče čovjeka koji se upušta u odnos s udanom ženom, na koji se način provodi smrtna kazna kojom je on kažnjen? Ja sam im odgovorio: Što se tiče čovjeka koji se upušta u odnos s udanom ženom pred svjedocima i usprkos ranijem upozorenju, njega se ima usmrtiti gušenjem i on ima udjela u budućem svijetu. Ali, onaj koji drugoga ponizi pred mnoštvom nema udjela u budućem svijetu. [Grijeh onih koji su ponizili Davida očito je ozbiljniji i teži od grijeha samoga Davida.] «77

Završetak kazne možda se najbolje vidi u činjenici da je David imao četvero djece s Bat-Šebom: »Evo imena djece koja mu se rodiše u Jeruzalemu: Šamua, Šobab, Natan, Salomon « (2 Sam 5,14; 1 Ljet 3,5). Talmud piše da je na kraju Bog prihvatio Davidovu molbu te mu je oprostio:

»David je poslije toga pred njim rekao: 'Gospodaru svemira, oprosti mi moj grijeh.' Bog mu je odgovorio: 'Oprošteno ti je.' Zatim je David zamolio: 'Daj mi milostivo znak naklonosti svoje, da vide moji mrzitelji i da se postide, jer si mi ti, o Svevišnji, pomogao, ti me utješio (Ps 86,17); pokaži mi znak za mojega života po kojem će svi znati da si mi oprostio.' Bog mu je odgovorio: 'Za tvojega života neću objaviti da ti je oprošteno, ali učiniti ću to za života tvojega sina, Salomona.' Talmud objašnjava: Kada je Salomon izgradio Hram i pokušao unijeti Kovčeg u Svetište, vrata su ostala čvrsto zatvorena i nisu se mogla otvoriti. Salomon je otpjevao dvadeset i četiri pjesme pohvalnice, ali molitva mu nije bila uslišana. Rekao je: 'Podignite, vrata, nadvratnike svoje, dižite se, dveri vječne, da

\footnotetext{
${ }^{54}$ Vidi 2 Sam 16,21-17,4.

${ }^{55}$ Vidi 2 Sam 11,2 i 16,20.

${ }^{56}$ Vidi BT Sanhedrin 107b (Steinsaltz).

${ }^{57}$ BT Sanhedrin 107a (Steinsaltz); s aram. prev. autor članka.
} 
uniđe Kralj slave! Tko je taj Kralj slave? Svevišnji silan i junačan, Svevišnji silan u boju!' (Ps 24,7-8). I rečeno je: 'Podignite, vrata, nadvratnike svoje, dižite se, dveri vječne, da uniđe Kralj slave! Tko je taj Kralj slave? Svevišnji nad Vojskama - on je Kralj slave! Selah' (Ps 24,9-10), ali nije dobio odgovora. No, kada je rekao: 'Bože Svevišnji, ne odvrati lica od svog pomazanika, spomeni se milòstî što ih dade sluzi svome Davidu!' (2 Ljet 6,42), odmah mu je odgovoreno i vrata su se otvorila (2 Ljet 7,1). U tome trenutku lica svih Davidovih neprijatelja potamnjela su te su nalikovala na čađavo dno lonca. I cijeli je židovski narod znao da je Presveti, Blagoslovljeni, oprostio Davidu njegov grijeh te da je samo po Davidovim zaslugama odgovoreno na Salomonovu molitvu. $\ll^{58}$

\section{Pitanje grijeha i kazne za grijeh}

\subsection{Pitanje načina}

Postavlja se vrlo uznemirujuće pitanje: Zašto Natan nije kritizirao Davida izravno zbog njegova grijeha? Zašto je u svojoj kritici pribjegao priči o ovci? Ako je preljub s udanom ženom doista tako težak grijeh, zašto se prorok poslužio implicitnom kritikom uz pomoć priče, a nije mu jednostavno i izravno iznio svoje zamjerke, što je bilo uobičajeno kad su izraelski proroci kritizirali kraljeve? ${ }^{59}$

Moguće je da je David doista vjerovao da nije sagriješio, barem ne formalno. Jer, kako je već prije pojašnjeno, zakonski gledano, Bat-Šeba je bila razvedena žena. Ali, postojao je moralni problem koji je prorok želio osvijestiti Davidu i omogućio mu je drukčiji pogled na vlastito ponašanje, iz druge perspektive, posredstvom pripovijesti. Iako se, kako je rečeno, može tvrditi da formalno između Urije i Bat-Šebe nije bilo bračne veze, ne može se sa sigurnošću reći da između njih dvoje nije postojao emotivni dodir. Čini se da prorok upravo to želi istaknuti govorom o emotivnoj navezanosti siromaha na njegovu ovcu:

»A siromah nemaše ništa, osim jedne jedine ovčice koju bijaše kupio. Hranio ju je i ona je rasla kraj njega i s njegovom djecom; jela je od njegova zalogaja, pila iz njegove čaše; spavala je na njegovu krilu: bila mu je kao kći« (2 Sam 12,3).

Tek je tada David shvatio da se prema Uriji ponio kao bogataš prema siromahu. Pouka proroka najčešće je bila usmjerena protiv nepravde, ${ }^{60}$ a ne nužno protiv nedostatka poštovanja prema halahi.

\footnotetext{
${ }^{58}$ BT Sanhedrin 107b (Steinsaltz); s aram. prev. autor članka.

${ }^{59}$ Vidi, primjerice, Iz 7,13; Jer 22,13-19; 1 Kr 21.

${ }^{60}$ Vidi, primjerice, Iz 58, Am 2 i dr.
} 


\subsection{Pitanje sadržaja}

Ako je Davidov grijeh bio tako ozbiljan da Biblija za njega koristi frazu: »Ali djelo koje učini David bijaše zlo u očima Svevišnjega« (2 Sam 11,26), kako je onda moguće da je poslije Urijine smrti David uzeo Bat-Šebu za ženu i doveo je u svoju kuću? Zašto prorok nije ustrajao na tome da David napusti Bat-Šebu? Zašto mu je dopustio da uživa u plodovima svojega grijeha? Očito, njegovo djelo nalik je Ahabovoj otmici Nabotova vinograda i nepravda viče do neba: »Umorio si i još si naslijedio? « $(1 \mathrm{Kr} 21,19) .{ }^{61}$ Osim toga, prorok odabire Salomona, sina Bat-Šebe kao nasljednika prijestolja i time zapravo pristaje na Davidov brak s Bat-Šebom.

No, može se objasniti da postoji i druga, plemenitija strana Davidove odluke da Bat-Šebu uzme za ženu. David je mogao odlučiti i da se ne oženi Bat-Šebom, mogao ju je napustiti u njezinu udovištvu i trudnoći, bilo je mnogo drugih koji su tako činili. ${ }^{62}$ Ali, on je odlučio preuzeti odgovornost za svoja djela. Može se usporediti Davidovo ponašanje prema Bat-Šebi i Judino prema Tamari (Post 38). Ta prispodoba može pojasniti narav obaju odnosa. Naravno, može se opaziti biološka poveznica između dvojice muškaraca - David je potomak Peresa koji je sin Tamare i Jude (Rut 4,18-22). Evo ključnih točaka u obje pripovijesti: (1) Odnosi su nastali između ljudi koji nisu bili u braku; (2) Posljedica tih zabranjenih odnosa je trudnoća; (3) Žene su očeve obavijestile o trudnoći, a očevi su priznali svoj grijeh.

Juda nije ignorirao Tamaru koja je s njime zatrudnjela. Bez obzira na posljedičnu sramotu, on preuzima punu odgovornost za svoje djelo. Kad je Bat-Šeba poslala Davidu poruku da je trudna, David ju je mogao odbaciti, čak i zanijekati svoju upletenostu u taj događaj. Dok je Tamara ipak imala nekakav dokaz o identitetu oca (Post 38, 25), Bat-Šeba nije imala ništa čime bi Davida mogla natjerati da preuzme odgovornost za svoje djelo. Ali on se ipak nije oglušio i nije zanijekao odgovornost prema Bat-Šebi niti ju je ostavio samu s posljedicama njihova čina. Osim toga, čini se da David nije imao dugoročnih planova u vezi s Bat-Šebom, jer je zapisano: »Zatim se ona vrati svojoj kući« (2 Sam 11, 4). Samo je jednom imao odnos s Bat-Šebom i da ona nije tada zanijela, sve bi se vjerojatno završilo na tome. Juda i David ne samo da su se pokajali, nego su se ponijeli časno i preuzeli punu odgovornost za svoje postupke i zaštitili su čast Tamare i Bat-Šebe. Upravo zahvaljujući takvom časnom djelu, obojica su zaslužila da ostanu vođe i kraljevi Izraela.

Drugo, u uvodu postavljeno pitanje glede kazne, u kontekstu je odgovora Svevišnjega na Saulov grijeh s Amalekom koji je usporediv s njegovim odgovo-

\footnotetext{
${ }^{61}$ Preveo je autor jer niti jedan hrvatski prijevod to nije preveo kao pitanje.

${ }^{62}$ Ovako se Amnon, njegov sin, ponio prema Tamari: »Dozva momka koji ga je služio i zapovjedi mu: 'Otjeraj ovu od mene, izbaci je i zaključaj vrata za njom! (...) Tako je Tamara ostala osamljena u kući svoga brata Abšaloma« (2 Sam 13,17-20). Vidi i Jeremijinu priču o preljubničkom kraljevstvu Izraela (Jr 4,1), čija je ljepota nestala tijekom trudnoće. Izrael je zatražio od preljubnika, oca djeteta, da je prihvati nakon što ju je muž napustio, ali i preljubnik ju je odbacio.
} 
rom i na Davidov grijeh. Dok je Saulu poslije grijeha kraljevstvo bilo oduzeto i sinovi su mu pomrli, David je ostao kraljem Izraela. Doista, četvero njegove djece je umrlo, ali se rodio i Salomon koji je naslijedio krunu i nastavio dinastiju. Očito je da takva usporedba budi osjećaj biblijske nepravde.

Riban $^{63}$ postavlja to pitanje i dodaje da David nije izgubio kraljevstvo zbog svojega grijeha, dok je Šaul, čija nedjela se doimaju manje ozbiljnima, izgubio kraljevstvo. On to objašnjava time što je Šaul, kada se suočio s prorokom Samuelom, odgovorio neizravno, kriveći narod, a sebe proglašavajući nedužnim. David je, pak, odgovorio izravno, priznao svoj grijeh i prihvatio odgovornost. ${ }^{64}$

Talmud objašnjava kako bi se trebao ponašati idealan, pošten vođa koji nije u sukobu interesa, koji je uzor i primjer svojem narodu. To je vođa koji se, bez obzira na visinu svojega položaja, ponizi pred svojim Stvoriteljem, koji ne nastoji prikriti i skriti svoj grijeh i ne srami ga se priznati, čak ni onda kad je počinjen bez zle nakane. Takav će vođa nesumnjivo biti uzor i vrijedan divljenja za svoj narod. Tora zapovijeda: »Ako nehotično pogriješi glavar i učini štogod što je Svevišnji, Bog njegov, zabranio i tako sagriješi, onda, kad ga obavijeste o prijestupu koji je počinio, neka kao svoj prinos donese muško jare bez mane« (Lev 4,22-23). Talmud taj redak objašnjava ovako:

»Mudraci nas poučavaju: u vezi kralja: 'Ako [ašer] nehotično pogriješi glavar' $($ Lev 4, 22). Rabin Johanan ben Zakai je rekao: Sretan [ašre] je naraštaj čiji kralj ima potrebu prinijeti žrtvu za svoj nesvjestan [prijestup]. Ako kralj toga naraštaja prinese žrtvu, svi morate reći koliko onda više mora običan čovjek prinijeti [kako bi okajao svoj grijeh, tj. on će svakako prinijeti žrtvu]. I, ako kralj prinese žrtvu za nesvjestan prijestup, morate reći da će to još više učiniti da bi okajao svoj hotimičan [prijestup, tj. svakako će se pokajati]. « ${ }^{65}$

Kada je grijeh takvoga vođe popraćen iskrenim i javnim kajanjem, on može poslužiti kao uzor cijelome narodu. Narod koji svjedoči spremnosti vođe da javno prizna svoj grijeh te zamoli za oprost, i čak prinese žrtvu pokajnicu, naučit će da nema sramote u kajanju i molbi za oprost. Taj će narod shvatiti da je i vođa samo čovjek s ljudskim slabostima, sposoban počiniti grijeh te će na narod utjecati hrabrost vođe da javno prizna svoj grijeh. I stoga bi taj naraštaj doista trebao biti sretan. Naraštaj čiji je vođa toliko savršen da nikada ne griješi, vjerojatno za vođu ima osobu koja je kadra učiniti sve da bi prikrila svoje grijehe. Takav naraštaj i takvi ljudi ne mogu biti sretni.

David je bio hrabar vođa. Iako je pogriješio, pokajao se i prihvatio presudu. Doista, Biblija više puta govori o tome kako se David ponizio kad je dobio presudu, a evo tek dva primjera: Davidovo ponašanje za vrijeme bijega iz Jeruza-

\footnotetext{
${ }^{63}$ Juda Azriel ben Natan, poznat kao RIBAN (1065-1105), Rašijev zet koji je napisao komentare na razne traktate.

${ }^{64}$ Vidi Šeelot uTešuvot Hahmei Provence, Jeruzalem, 1967, 71. Paragraf »Nictanen Dami«.

${ }^{65}$ BT Horajot 10b (Steinsaltz); s aram. prev. autor članka.
} 
lema poslije pobune njegova sina Abšaloma, što je David shvatio kao dio Božje kazne, i drugi iz Psalama:

»Bijaše ondje i Sadok i s njim svi leviti koji su nosili Kovčeg Božji. I oni spustiše Kovčeg Božji kraj Ebjatara dok sav narod nije izišao iz grada. Tada kralj reče Sadoku: 'Odnesi Kovčeg Božji natrag u grad. Ako nađem milost u Svevišnjega, on će me dovesti natrag i dopustiti mi da opet vidim njega i njegovo prebivalište. A ako rekne ovako: Nisi mi po volji! - onda evo me, neka čini sa mnom što je dobro u njegovim očima!... David se uspinjao na Maslinsku goru, sve plačući, pokrivene glave i bos, i sav narod koji ga je pratio iđaše pokrivene glave i plačući« (2 Sam 15,24-26.30).

U knjizi Psalama David, veliki pjesnik, najbolje izriče svoje osjećaje:

»Psalam Davidov kad je prorok Natan došao k Davidu poslije njegova grijeha s Bat-Šebom. 'Smiluj mi se, Bože, po milosrđu svome, po velikom smilovanju izbriši moje bezakonje! Operi me svega od moje krivice, od grijeha me mojeg očisti! Bezakonje svoje priznajem, grijeh je moj svagda preda mnom. Tebi, samom tebi ja sam zgriješio i učinio što je zlo pred tobom’« (Ps 51,1-6).

\section{Zaključak}

Iako se Davida smatra jednim od velikih i dobrih kraljeva izraelskog naroda, kako u ratu, tako i u miru, vođom iznimnih sposobnosti, silne duhovne snage i izrazite ljubavi prema Bogu, Biblija ne skriva njegov pad. Bez sumnje, njegov najveći duhovni i moralni pad je njegov odnos s Bat-Šebom. U članku se nastojalo preispitati kako Mudraci i poznavatelji rabinske literature, od vremena Talmuda sve do srednjega vijeka, tumače Davidove postupke te kako su se neki odmaknuli od tekstovnoga razumijevanja Svetoga pisma i što ih je na to navelo.

Vidjelo se da postoje dvije glavne škole, jedna koja nastoji umanjiti grijeh i druga, koja ga čvrsto odbacuje, ali naglašava Davidovo kajanje i na njega se usredotočuje. Kao svojevrstan zaključak evo riječi rabina don Isaaca Abarbanela, ${ }^{66}$ prognanika iz Španjolske, koji je bio zagovornik druge škole. On objašnjenje Mudraca iz Talmuda o uvjetnom razvodu smatra agadičkim midrašem, ${ }^{67} \mathrm{koji}$ nije obvezujući i na neki način se čak i suprotstavlja jednostavnom razumijevanju biblijskoga teksta pa stoga odbacuje midraško tumačenje:

»Pouke naših Mudraca u ovome pitanju su midraška objašnjenja, i na njih se neću osvrtati... Kako možemo reći 'on je nastojao počiniti [prijestup], ali ga nije počinio'? Tekst jasno svjedoči tom zlome činu u cijelosti; da David nije sagrije-

\footnotetext{
${ }^{66}$ Don Isaac ABARBANEL (1437-1509) - komentator, filozof i političar, potomak kralja Davida, vođa španjolskog židovstva, portugalski rizničar u doba kralja Alfonsa Petog kao prebjeg iz Španjolske.

${ }^{67}$ Agadički midraš - tumačenje; komentari Tore; dvije su vrste midraša: agadički (pripovjedački) i halahički (propisujući); prikupljeni u zbirkama (vidi još o Midrašu u DaDon, Żidovstvo..., 503-505).
} 
šio zašto bi rekao 'Sagriješio sam protiv Svevišnjega!' (2 Sam 12,13)? I zašto bi se tako iskreno pokajao govoreći: 'Bezakonje svoje priznajem, grijeh je moj svagda preda mnom' (Ps 51,5)? Osim toga, redak koji navodi kao potporu [pristupu koji ga nastoji osloboditi] - 'David je imao uspjeha na svim svojim putovima, jer Svevišnji bijaše s njim' (1 Sam 18,14) pojavljuje se prije toga događaja i ne isključuje mogućnost da je David poslije toga sagriješio. Jer, čak i ako je u to vrijeme bio razborit, mudar i uspješan u svim svojim djelima i Bog je bio s njime ma što učinio, onda bi Bog jamačno bio s njime ako je i griješio, jer je prihvatio svoju kaznu i pokajao se. Stoga ne mogu prihvatiti umanjivanje Davidova grijeha i neću pokušati nijekati jednostavnu istinu. Jednako tako, kako bih mogao prihvatiti tvrdnje da su muškarci davali dokumente o razvodu svojim ženama? Jer, redak koji navode kao dokaz svojim tvrdnjama uopće na to ne upućuje. [Nadalje,] David je rekao Uriji da te noći pođe kući i da se nakon toga vrati [na bojišnicu] ujutro, što upućuje na to da nije bilo nikakva razvoda [u biti] i da bi njihov odnos bio ispravan i primjeren. To se nadalje dotiče i mišljenja Mudraca u Talmudu da se Urija pobunio protiv kralja te da je zaslužio smrt jer je rekao: 'I moj gospodar Joab' - nazivajući Joaba 'svojim gospodarom' dok je stajao pred kraljem. Jednom rječju, ako ga tekst naziva grešnikom i ako on sam priznaje svoj grijeh, kako bi itko mogao počiniti pogrešku i ne povjerovati mu? Čini mi se bolje reći da je doista teško sagriješio te da je iskreno i promišljeno priznao svoj grijeh te se potpuno pokajao i prihvatio svoju kaznu - i upravo su mu stoga svi njegovi grijesi bili oprošteni. ${ }^{68}$

Prema Abarbanelovu shvaćanju problematike, David doista jest sagriješio, ali znak njegove veličine bilo je potpuno i apsolutno pokajanje. Upravo zato Bog mu je grijehe oprostio i prihvatio je njegovu žrtvu. Doista, naši Mudraci nisu nastojali biblijske osobe pokazati kao anđele, kako je rekao kralj Salomon: »Na zemlji nema pravednika koji, čineći dobro, ne bi nikad sagriješio « (Prop 7,20). Njihova je veličina u iskrenu i potpunu kajanju. Osim kralja Davida, naši Mudraci spominju i kritiziraju grijehe osoba kao što su Adam, ${ }^{69}$ Noa, ${ }^{70}$ Abraham, ${ }^{71}$ Ruben (Post 35,22), Josip, ${ }^{72}$ Mojsije (Br 20,12), Salomon ${ }^{73}$ i mnogi drugi. U odnosu s Bat-Šebom David je teško sagriješio, ali mora se razumjeti da taj grijeh ne govori o njegovoj posvemašnjoj osobnosti. Taj ružan događaj samo je iznimka. Biblija pripoviješću o odnosu Davida i Bat-Šebe šalje poruku: i pravednik je samo čovjek koji posrće i pada, ali se bori sa sobom samim, shvaća i priznaje grijeh te zbog njega žali. Pravednik nije savršen čovjek koji ne griješi, jer takvog čovjeka nema. Pitanje je koliko pomno pazi da ne počini grijeh i kako se ponaša i bori nakon što je grijeh počinjen.

\footnotetext{
${ }^{68}$ Abarbanelov komentar Biblije (Varšava, 1862), 2 Sam kraj 11. poglavlja; s heb. prev. autor članka.

${ }^{69}$ BT Sanhedrin 38b (Steinsaltz).

${ }^{70}$ Zohar I, 67 i 254.

${ }^{71}$ BT Nedarim 32a (Vilne).

${ }^{72}$ BT Sota 36b (Steinsaltz).

${ }^{73}$ JT Sanhedrin 10,2; BT Jebamot 76b (Vilne).
} 


\section{Kotel DaDon* \\ The Story of David and Bat Sheba According to Rabbinic Literature \\ Summary}

In this article the author analyses one of the most interesting stories in the Bible, the affair of King David and Bat-Sheba according to sources from rabbinic literature. King David was a king, a spiritual lider, composer of Psalms, a great Torah scholar, the progenitor of the Jewish kingly dynasty and, according to the Jewish tradition, even the Messiah is supposed to be his descendant. However, according to the biblical story, David sinned severely. He committed sins of adultery and murder of an innocent, sins that don't fit his image. The main task of this work is to explain, based on rabbinic literature, what exactly happened. Did king David fall from heavenly hights into a deep pit? The first part of the article consists of a general introduction, followed by a review of the biblical episode. The central part of this article is the Sages' interpretation of king David and Bat Sheba affair, discussing the relationship between Uriah and Bat Sheba and the question of the adultery, followed by an analysis of the sin and punishment and various questions it raises. The author uses many sources from the rabbinical literature since Talmudic times through the middle Ages until modern times. Much of this literature is translated into Croatian from Hebrew and Aramaic for the first time by the author.

Key words: Bat Sheba, Bible, David, Midrash, Talmud, Torah, Uriah.

(Translated into English by the author)

\footnotetext{
* Kotel DaDon, PhD, Assoc. Prof., University of Zagreb, Faculty of Humanities and Social Sciences, Chair for Judaic studies; Chief Rabbi, The Bet Israel Jewish Community of Croatia; Address: Ivana Lučića 3, HR-10000 Zagreb, Croatia; E-mail: kdadon@gmail.com.
} 